\title{
Arctic Fires Re-Emerging
}

Jessica L. McCarty ${ }^{1}$, Thomas E. L. Smith², Merritt R. Turetsky ${ }^{3}$

${ }^{1}$ Assistant Professor, Department of Geography \& Director, Geospatial Analysis Center, Miami University, Oxford, OH, USA

${ }^{2}$ Assistant Professor, Department of Geography \& Environment, London School of Economics \& Political Science, London, UK

${ }^{3}$ Director, Institute of Arctic and Alpine Research \& Associate Professor, Ecology and

Evolutionary Biology Department, University of Colorado, Boulder, CO, USA

Underground smouldering fires resurfaced early in 2020, contributing to the unprecedented wildfires that tore through the Arctic this spring and summer. An international effort is needed to manage a changing fire regime in the vulnerable Arctic.

Wildfires are not a novel phenomenon in the Arctic, however 2020's fire season began two months early and has been far more severe than usual. While increasing fire activity in Boreal forests to the south ${ }^{1,2}$ and an unusually warm winter in the Arctic ${ }^{3}$ have led some to suggest that this uptick in wildfires was inevitable, there is still uncertainty about their source and their local and global impact. Here, we discuss how the wildfires in the Arctic are changing and how the input and expertise of local and Indigenous communities will be essential to determine whether this year is an anomaly or the beginning of a new fire regime.

Early burning season. Wildland fire experts generally believe that extremely early season fires in the Arctic - before aboveground vegetation tends to be flammable - are caused by holdover or so-called "zombie fires". One of the most fascinating aspects of zombie fires is that they represent a continuation of a previous growing season's fire rather than a new ignition source, such as lightning or campfires. Zombie fires can smoulder in carbon-rich peat below the surface for months or years ${ }^{4}$, often only detectable through smoke released at the surface and can even occur through cold winter months despite heavy snowmelt ${ }^{5}$. These types of fires in general are poorly understood, including their impacts on fuels and emissions of greenhouse gases and aerosols to the atmosphere ${ }^{6}$. However, if these fires, their increasing prevalence and large burn areas or deep burning conditions drive substantial emissions, then this would represent a strong feedback in the Arctic fire regime that needs to be considered by Earth system models or simulations of global biomass burning.

Fire in fire-resistant landscapes. Evidence from 2019 and 2020 suggests that extreme temperatures accompanied by drying are increasing the availability of surface fuels in the Arctic. New tundra vegetation types, including dwarf shrubs, sedges, grasses and mosses, as well as surface peats, are becoming vulnerable to burning and what we typically consider to be "fire resistant" ecosystems, such as tundra bogs, fens, and marshes are burning (Figure 1). While wildfires on permafrost in Boreal regions of Siberia are not uncommon ${ }^{7}, 2020$ 's fires are unusual in that more than $50 \%$ of the detected fires above $65^{\circ} \mathrm{N}$ occurred on permafrost with high ice content. Ice-rich permafrost is considered to contain the most carbon-rich soils in the Arctic $^{8}$ and burning can accelerate thaw and carbon emission rates ${ }^{9}$. Burning of ice-rich 
permafrost can form overhangs and tunnels ${ }^{10}$ leading to subsidence, localized flooding and the formation of permafrost thaw features, in particular lakes and wetlands (Figure 1). Such landscape features are also associated with large fluxes of permafrost carbon to the atmosphere, mostly as methane ${ }^{8,11}$, further exacerbating climate feedbacks.

The challenge of detecting change. Current modeling tools used to predict biomass burning around the world often cannot be relied upon in the Arctic because of lack of data on ignition and fuel types. The severe 2020 Arctic fires emphasize the urgent need to investigate the role of holdover (zombie) fires versus new ignitions in driving Arctic fires and to efficiently assimilate this information into current global satellite products and emission databases. New tools and approaches are required to quantify the influence of zombie fires on surface burning and their sources - whether they are caused by severe late-summer surface fires in the Arctic, or point sources such as campfires and pile burning.

Satellite imagery could help map the extent and timing of surface fires, but ground-truthing data needed to interpret those remote images are sparse. For example, monitoring changes in surface elevation and inundation over time following these Arctic fires will be useful for understanding the resilience of ice-rich permafrost to a changing Arctic fire regime. But not all Arctic fires will influence carbon emissions in the same way and it will be important to understand where old legacy carbon stored in peats or permafrost is vulnerable to burning and post-fire changes in the environment ${ }^{2}$, which will require in situ, specialized knowledge. Similarly, current approaches to monitoring biomass burning are focused on aboveground fuels, while detection of belowground holdover fires remains a challenge. While new geostationary ${ }^{12}$ and polar-orbiting satellite products ${ }^{13}$ may help improve the detection of holdover fires such as those observed in the 2020 Arctic fires, in situ and local information ${ }^{14}$ about what is burning and where will be vital if we are to incorporate these high latitude fires into our global understanding of fire activity.

A global call to action. It will be a tremendous collaborative, inclusive and multi-disciplinary effort to tackle the intensifying Arctic fire regime, but it is one of critical importance. We will not understand how the Arctic fire regime is changing without interdisciplinary collaborations between various knowledge holders. Addressing the gaps in our current understanding will require critical input from Indigenous and local communities and collaboration across scientific disciplines. Local communities have the ability to access remote locations and enable invaluable long-term in situ observations, including signs of holdover fires during winter months, guiding coordinated research across the full range of fire management, fire ecology, and fire-climate impact communities.

Changes in the Arctic fire regime will have strong feedbacks on global climate, but to what extent will not be clear until we better understand the dynamics and full impact of holdover and surface fires on carbon emissions. International and interdisciplinary coordination will be essential to monitor rapid changes in this critical ecosystem, but Indigenous and local communities who are the first to experience these changes must be empowered to lead and contribute to these coordination efforts. Existing intergovernmental forums invested in 
safeguarding the pan-Arctic and involve Arctic Indigenous peoples as permanent participants, such as the Arctic Council, are well placed to shepherd forward a pan-Arctic fire monitoring system. This will require monitoring networks spanning ground-based experiments to remote sensing and Earth system models, driven by knowledge co-production with Indigenous, traditional, and modern Arctic communities and economies.

The burning Arctic is a global issue that requires a global solution. While the expertise of the Indigenous communities of the North and Arctic nations will be central to any success, we cannot expect them to shoulder the responsibility alone.

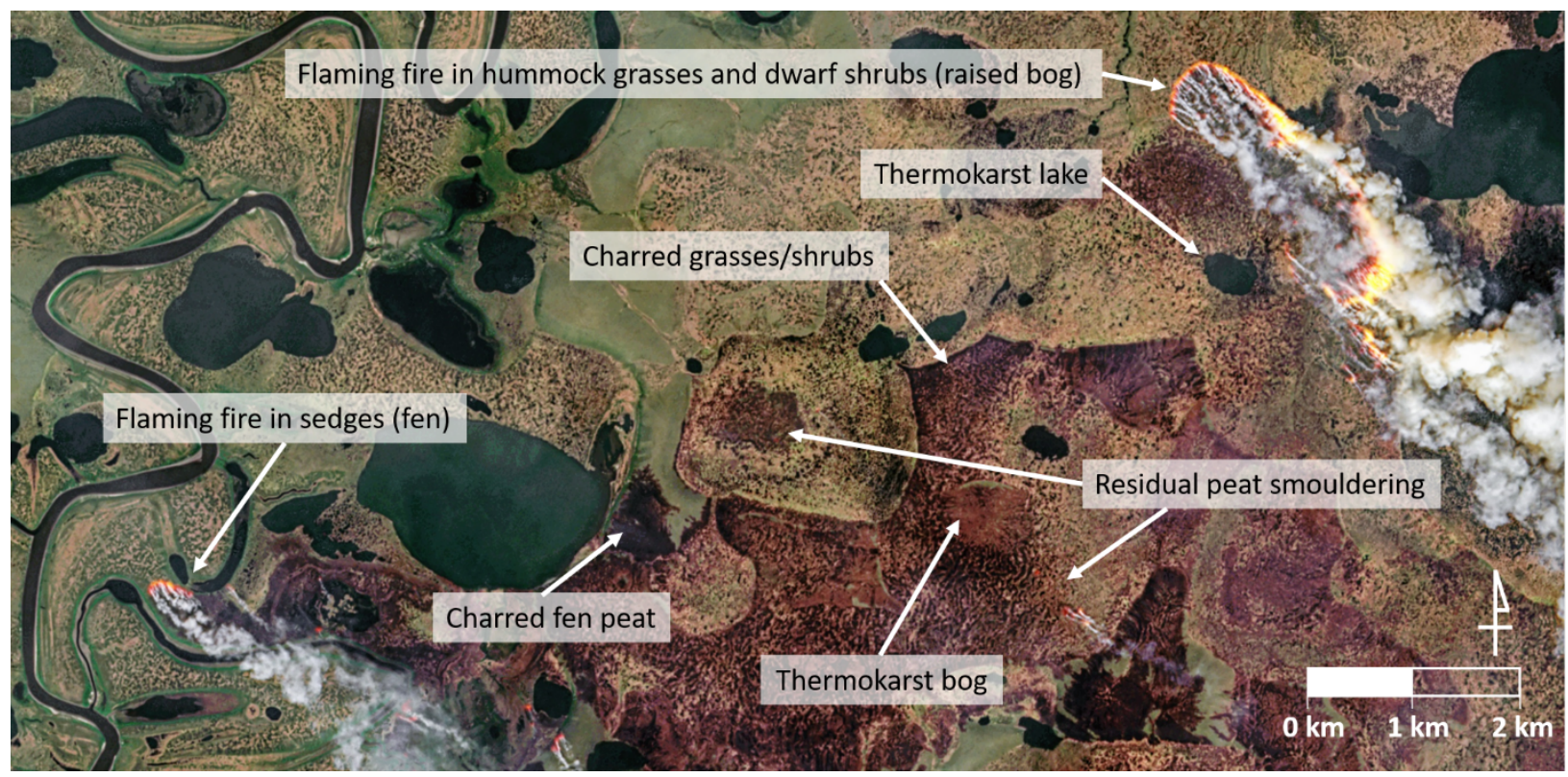

Figure 1: Composite satellite image from Sentinel-2 (true colour composite with MWIR overlay showing location of active burning in shades of orange). The image depicts a number of fires at $71.32^{\circ} \mathrm{N}, 144.49^{\circ} \mathrm{E}$ (Sakha Republic, Russia) on 25 June 2020; a scene that is typical of dozens of fires burning across tundra ecosystems in June 2020. Thermokarst bogs and thaw lakes also are present on this landscape with nearby smouldering, suggesting direct relationships between burning and permafrost thaw in this region of cold but ice-rich permafrost. Image processed by Pierre Markuse (https://pierre-markuse.net/). Contains modified Copernicus Sentinel data (European Union, 2020).

\section{References:}

1. Kasischke ES, Verbyla DL, Rupp TS, McGuire AD, Murphy KA, Jandt R, et al. Alaska's changing fire regime-implications for the vulnerability of its boreal forests. Canadian Journal of Forest Research 2010, 40(7): 1313-1324. 
2. Walker XJ, Baltzer JL, Cumming SG, Day NJ, Ebert C, Goetz S, et al. Increasing wildfires threaten historic carbon sink of boreal forest soils. Nature 2019, 572(7770): 520-523.

3. Smolyanitsky V. November 2019 - April 2020 Arctic Seasonal Review. 2020 [cited]Available from: https://arctic-rcc.org/sites/arctic-rcc.org/files/presentations/acfspring-2020/ACF-5 May28 1610 Arctic summary winter-spring 2019-2020.pdf

4. $\quad \mathrm{Hu} Y$, Fernandez-Anez N, Smith TE, Rein G. Review of emissions from smouldering peat fires and their contribution to regional haze episodes. International Journal of Wildland Fire 2018, 27(5): 293-312.

5. Information AWF. Despite heavy snow melt, Deshka Landing hot spots still smoldering. 2020 [cited]Available from: https://akfireinfo.com/2020/04/24/despite-heavy-snow-meltdeshka-landing-hot-spots-still-smoldering/

6. Prosperi P, Nloise M, Tubilleo FN, Conchedda G, Rossi S, Boschetti L, Salvatore M, Bernoux M. New estimates of greenhouse gas emissions from biomass burning and peat fires using MODIS Collection 6 burned areas. Climatic Change 2020, 161: 415-432.

7. Kirdyanov AV, Saurer M, Siegwolf R, Knorre AA, Prokushkin AS, Churakova OV, et al. Long-term ecological consequences of forest fires in the continuous permafrost zone of Siberia. Environmental Research Letters 2020, 15(3): 034061.

8. Olefeldt D, Goswami S, Grosse G, Hayes D, Hugelius G, Kuhry P, McGuire AD, Romanovsky VE, Sannel ABK, Schuur EAG, Turetsky MR. Circumpolar distribution and carbon storage of thermokarst landscapes. Nature communications 2016, 7(1): 1-11.

9. Gibson CM, Chasmer LE, Thompson DK, Quinton WL, Flannigan MD, Olefeldt D. Wildfire as a major driver of recent permafrost thaw in boreal peatlands. Nature communications 2018, 9(1):1-9.

10. Usup A, Hashimoto Y, Takahasi H, Hayasaka H. Combustion and thermal characteristics of peat fire in tropical peatland in Central Kalimantan, Indonesia. Tropics 2004, 14: 1-19.

11. Turetsky MR, Abbott BW, Jones MC, Anthony KW, Olefeldt D, Schuur EA, et al. Carbon release through abrupt permafrost thaw. Nature Geosciences 2020, 13(2): 138-143.

12. Xu W, Wooster MJ, Kaneko T, He J, Zhang T, Fisher D. Major advances in geostationary fire radiative power (FRP) retrieval over Asia and Australia stemming from use of Himarawi-8 AHI. Remote Sensing of Environment 2017, 193: 138-149.

13. Wooster MJ, Xu W, Nightingale T. Sentinel-3 SLSTR active fire detection and FRP product: Pre-launch algorithm development and performance evaluation using MODIS and ASTER datasets. Remote Sensing of Environment 2012, 120: 236-254.

14. Kirillina K, Shvetsov EG, Protopopova VV, Thiesmeyer L, Yan W. Consideration of anthropogenic factors in boreal forest fire regime changes during rapid socio-economic 
development: case study of forestry districts with increasing burnt area in the Sakha Republic, Russia. Environmental Research Letters 2020, 15(3): 035009. 